\title{
THE ANTIOXIDANT STUDIES OF TWO MEDICINAL PLANTS, SPHAERANTHUS INDICUS AND PSOPHOCARPUS TETRAGONOLOBUS
}

\author{
VIJAYALAKSHMI N, MUDIGANTI RAM KRISHNA RAO*
}

Department of Industrial Biotechnology, Bharath Institute of Higher Education and Research, Chennai - 600 073, Tamil Nadu, India. Email: mrkrao1455@gmail.com

Received: 25 September 2018, Revised and Accepted: 13 November 2018

\section{ABSTRACT}

Objective: The present study deals with the antioxidant assays of the different leaf extracts of two medicinal plants, Sphaeranthus indicus and Psophocarpus tetragonolobus.

Methods: Dried leaves of S. indicus and P. tetragonolobus were packed in separate round bottom flasks for sample extraction using ethanol, methanol, hexane, and distilled water as solvents for $72 \mathrm{~h}$, and the extracts were collected after evaporating the solvents. Antioxidant studies of the various extracts were performed by 1-diphenyl-2-picrylhydrazyl and Ferric Reducing Ability of Plasma assays.

Results: Among the two plants studied, S. indicus showed better 2-diphenyl-1-picryl-hydrazyl (DPPH), scavenging activity than P. tetragonolobus with

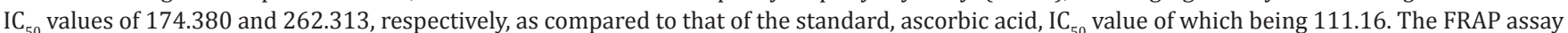
results for both the plants indicated that the methanol fractions showed closer results when compared with standards, ascorbic acid and quercetin.

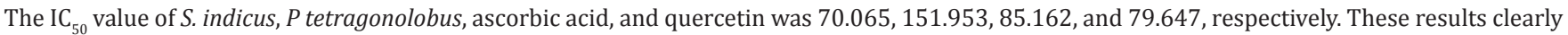
indicate that $S$. indicus methanol fraction had better antioxidant activity when compared to both standards.

Conclusion: It is concluded that $S$. indicus and P. tetragonolobus have excellent antioxidant activities which could be the major contributing factors for their medicinal roles. Further studies in this direction are being carried on.

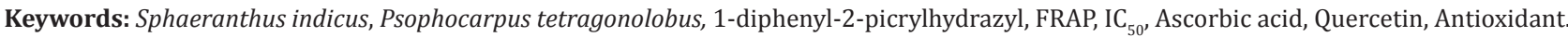

(C) 2019 The Authors. Published by Innovare Academic Sciences Pvt Ltd. This is an open access article under the CC BY license (http://creativecommons. org/licenses/by/4. 0/) DOI: http://dx.doi.org/10.22159/ajpcr.2019.v12i2.29951

\section{INTRODUCTION}

The complementary and alternative medicine, which is also known as traditional medicinal practice, depends mostly of plants and other natural products such as minerals as sources of medicines. Ayurveda and Sidhha forms of medical practices are age-old and time-tested practices. The use of herbs, shrubs, trees, and roots as sources of medicine is a common practice for the folklore. However, the fact remains that these forms of medicines require rigorous standardization to eliminate the ambiguity about their veracity. Tremendous advancements have taken place toward analytical procedures, and these technologies must be used for proving the efficacy of the Ayurvedic and other forms of alternative medicine forms. Some work in this regard is forthcoming, which is a welcome sign [1-7]. This exercise will help in delivering cheap, affordable medicines with the additional advantage of their being less toxic in contrast to the modern-day molecular medicines. The present work is a step in this direction. Two medicinal plants, namely Sphaeranthus indicus and Psophocarpus tetragonolobus, were taken for the present study. These plants are used as folklore medicine for various ailments in India and other countries. There are numerous scientific reports on the medicinal roles of these two plants.

S. indicus is known as Maha Mundi or Mundi in Ayurveda. The medicinal properties such as antiviral, antibacterial, antifungal, neuroprotective, central nervous system depressant, anticonvulsive, fertility enhancing, analgesic, antipyretic, hepatoprotective, antidiabetic, antioxidant, and anticancer are reported [8-16]. The phytochemical and gas chromatography-mass spectrometry (GC-MS) analysis of various extracts of the leaves of $S$. indicus was reported by Rao and Vijayalakshmi, 2018 [17].
P. tetragonolobus is a tropical leguminous plant known as "poor man's food" since the leaves, flowers, roots, and pods are eaten raw or cooked. This plant is known for its nutritional value containing Vitamin A, Vitamin C, calcium, iron, proteins, and fats. Apart from being an edible plant, the fruits are reported to have anti-inflammatory, antioxidant, and anti-nociceptive activities [18].

Various plant parts have antimicrobial activities [19]. This plant is rich in erucic acid and polyunsaturated fatty acid which work as antitumor and anti eczema [20]. The decoction of the leaves was used to treat smallpox [21]. Ethnobotanically, the aqueous extract of the leaves is given to pregnant ladies after $5^{\text {th }}$ month in combination with other plant leaves to keep the fetus healthy. The phytochemical and GC-MS analysis of various extracts of the leaves of this plant was reported by Rao et al., 2018 [22]. The present study deals with the antioxidant study of different extracts of the leaves of $S$. indicus and P. tetragonolobus.

\section{METHODS}

The plants such as $S$. indicus and P. tetragonolobus were identified a qualified botanist from Madras University, Chennai. $100 \mathrm{~g}$ of dried powder of the leaves of $S$. indicus and P. tetragonolobus was packed in separate round bottom flasks for sample extraction using ethanol, methanol, hexane, and distilled water as solvents. The extraction was conducted with $300 \mathrm{ml}$ of the solvent for $72 \mathrm{~h}$. At the end of the extraction, the solvents were concentrated under reduced pressure and the crude extracts were stored in the refrigerator. The extracts were collected separately and filtered, and the filtrate is used for antioxidant studies. 


\section{Antioxidant studies}

The radical scavenging effects

Dot-Plot Rapid Assay

The rapid screening assay was performed by the method proposed by Solver-Rivas et al. [23].

\section{Procedure}

Aliquots of plant extracts were spotted carefully on thin-layer chromatography (TLC) plates and dried. The sheets bearing the dry spots were placed upside down for 30-60 s in 1-diphenyl-2picrylhydrazyl (DPPH) solution, and the layer was dried. The stained silica layer revealed a purple background with yellow spots, which showed radical scavenging capacity.

TLC procedure was followed for a total of five samples. The first one had $10 \%$ dilution, whereas the subsequent four were having serial dilutions by $10 \%$ each. To visualize the spots, the amount of the above five samples was charged with decreasing order of quantity, i.e., 100, $80,60,40$, and $20 \mu \mathrm{l}$, respectively. Since the spots were visible normally, we have deviated from the procedure by not keeping the TLC plates in iodine chamber or treating with sulfuric acid.

DPPH spectrophotometric assay

The antioxidant activity of the plant extracts was examined on the basis of the scavenging effect on the stable DPPH free radical activity as per the method of Braca [24].

Principle

DPPH radical reacts with an antioxidant compound that can donate hydrogen and get reduced. DPPH, when acted by an antioxidant, is converted into diphenyl picryl hydrazine. This can be identified by the conversion of purple to light yellow color.

Chemicals and reagents

1, DPPH, methanol, ascorbic acid, and sample were used.

Antioxidant activity (DPPH free radical scavenging activity) determination

DPPH solution (DPPH - $1 \mathrm{mg} / \mathrm{ml}$ in methanol) was freshly prepared and kept in the dark at $4^{\circ} \mathrm{C}$. $3.7 \mathrm{ml}$ of absolute methanol was added to all test tubes including blank. The concentration such as 100 , $200,300,400$, and $500 \mathrm{mg}$ of ascorbic acid was dissolved in $1 \mathrm{ml}$ of distilled water which was prepared separately, and $100 \mu \mathrm{l}$ of respective ascorbic acid sample was added to the tubes marked as blank. The same concentration was prepared for water extract of $S$. indicus and P. tetragonolobus, and $100 \mu \mathrm{l}$ of respective samples were added to all tubes marked as tests. $100 \mu \mathrm{l}$ of distilled water was added to the blank test tube. $200 \mu \mathrm{l}$ of DPPH reagent was added to all the test tubes including blank. All the test tubes were incubated at room temperature and in the dark for $30 \mathrm{~min}$. The mixture was left to stand for $5 \mathrm{~min}$, and absorbance was measured spectrophotometrically at $517 \mathrm{~nm}$. Methanol was used to set the absorbance zero.

The radical scavenging activities of the tested samples, expressed as a percentage of inhibition, were calculated according to the following equation (Yen and Duh) [25]. A percentage inhibition versus concentration curve was plotted, and the concentration of sample required for $50 \%$ inhibition was determined and represented as $\mathrm{IC}_{50}$ value for each of the test solutions. The results are mentioned in Table 1.

Table 1: The FRAP assay results for all the extracts of Sphaeranthus indicus leaves

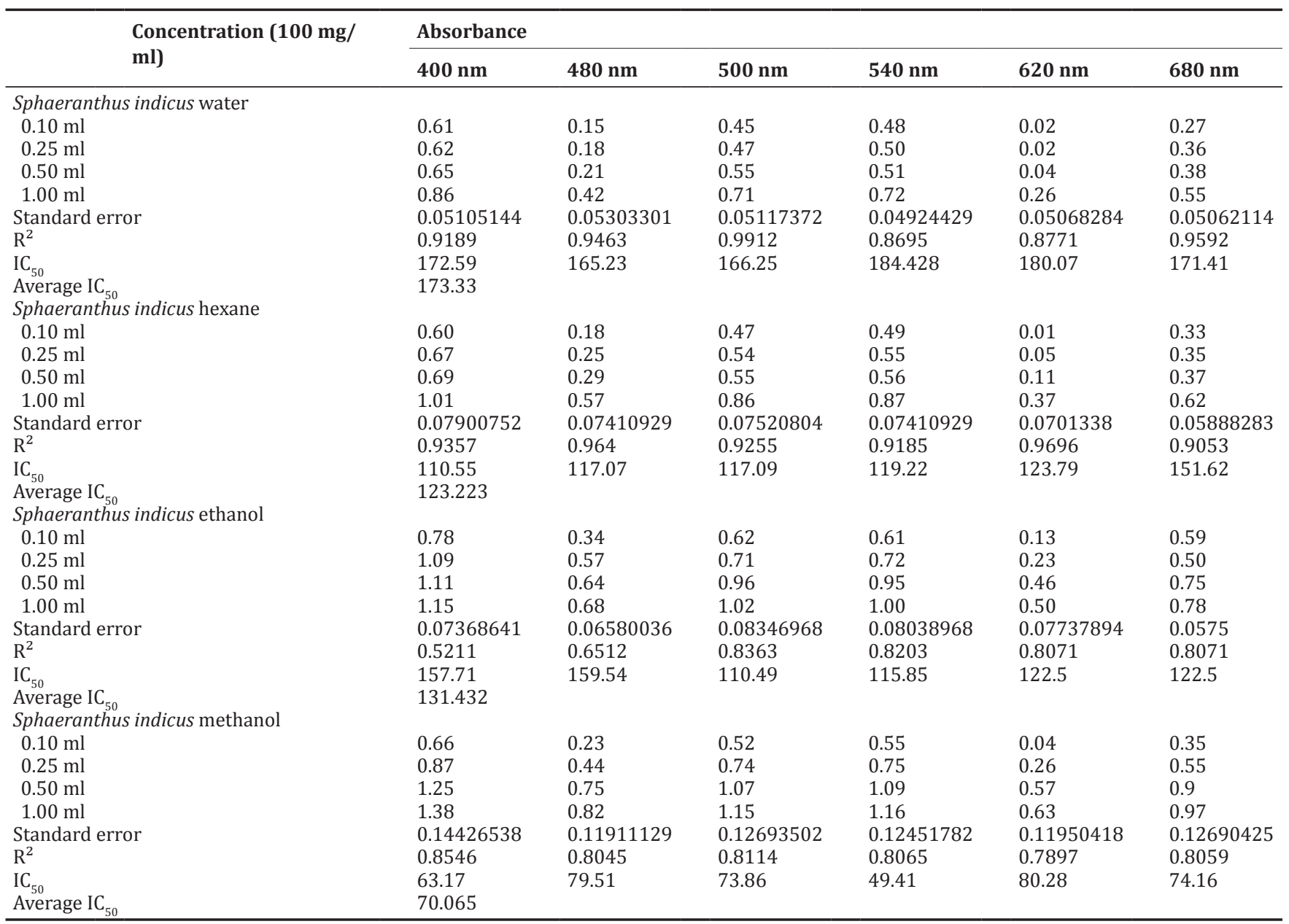


Calculation for percentage scavenging activity

$\%$ Scavenging antioxident $=\frac{(\text { absorbanceat blank }- \text { absorbanceattest })}{\text { absorbanceatblank }} \times 100$ absorbanceat blank

\section{Determination of reducing property (reducing power assay)}

The reducing power of the herbal medicine extract was determined by a slightly modified method (Oyaizu) [26]. The reducing ability of the drug extract was measured by the transformation of $\mathrm{Fe} 3+-\mathrm{Fe} 2+$ in the presence of the extract at 400-680 $\mathrm{nm}$. Increased absorbance of the reaction mixture indicates increased reducing power. $100 \mathrm{mg}$ of $S$. indicus and $P$. tetragonolobus water extract was dissolved in 1 $\mathrm{ml}$ of distilled water separately, and from this, concentrations such as $0.10,0.25,0.50$, and $1 \mathrm{ml}$ were taken in respective tubes. It was mixed with phosphate buffer $(2.5 \mathrm{ml}, 0.2 \mathrm{M}$, and $\mathrm{pH} 6.6)$ and potassium ferricyanide $(2.5 \mathrm{ml}, 1 \%)$. The mixtures were then incubated at $50^{\circ} \mathrm{C}$ for 20 min. Aliquots (2.5 ml) of trichloroacetic acid (10\%) were added to each mixture, which were then centrifuged for $10 \mathrm{~min}$ at $1000 \mathrm{rpm}$. The upper layer of the solutions $(2.5 \mathrm{ml})$ was mixed separately with distilled water ( $2.5 \mathrm{ml})$ and iron (III) chloride $(0.5 \mathrm{ml}, 0.1 \%)$, and the absorbance levels were measured at 400-680 nm using a colorimeter.

\section{RESULTS AND DISCUSSION}

The Dot-Plot Assay results of S. indicus and P. tetragonolobus water, hexane, ethanol, and methanol extracts, respectively, with increasing concentrations of sample are shown in Figs. 1 and 2, respectively. From the above-mentioned results, it is clear that $S$. indicus and $P$. tetragonolobus leaf extracts show promising antioxidant potentials. The Dot Plot experiment results indicated that, for all the four extracts of $S$. indicus and P. tetragonolobus, i.e., water, hexane, ethanol, and methanol, there was a gradual increase in the reactions with an increase in concentration, as visualized by the color changes, i.e., purple to light

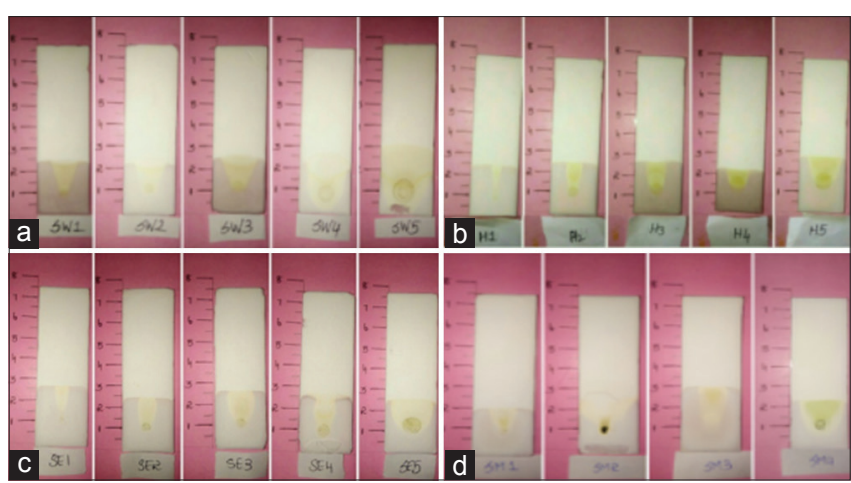

Fig. 1: (a-d) Dot-Plot Assay results of Sphaeranthus indicus water, hexane, ethanol, and methanol extracts, respectively, with increasing concentrations of sample

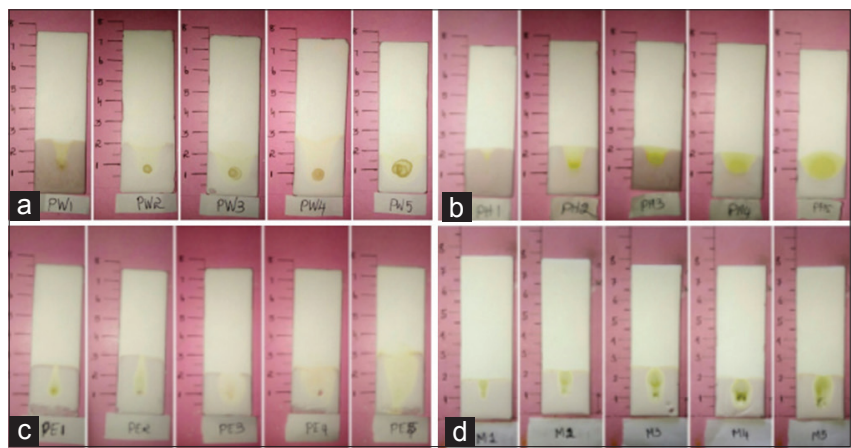

Fig.2: (a-d) Dot-Plot Assay results of Psophocarpus tetragonolobus water, hexane, ethanol, and methanol extracts, respectively, with increasing concentrations of sample yellow. These results indicated that $S$. indicus and $P$. tetragonolobus show antioxidant activities in all the concentrations observed.

The DPPH scavenging activities of S. indicus and P. Tetragonolobus water extracts are shown in Fig. 3, Fig. 4 and Fig. 5, respectively. The FRAP assay results of $S$. indicus and $P$. tetragonolobus are shown in Fig. 6(a-d) and Fig. 7 (a-f), whereas the comparative $\mathrm{IC}_{50}$ values for all extracts for both plants with ascorbic acid and quercetin are shown in Fig. 8.

The DPPH scavenging activities of S. Indicus and P. tetragonolobus water extracts as compared to the standard, ascorbic acid, are represented in Table 2. The FRAP assay results for $S$. indicus and $P$. tetragonolobus are shown in Tables 2 and 3, respectively. Table 4 indicates the FRAP assay results for standards, ascorbic acid and quercetin. Among the two plants studied for DPPH activity, $\mathrm{S}$ indicus had better $\mathrm{IC}_{50}$ value (174.380) when compared to P. tertragonolobus (262.313) the standard being Ascorbic acid with $\mathrm{IC}_{50}$ value (111.16).

Similarly, the FRAP assay results for both the plants also indicated that the methanol fractions of both plants showed closer results when

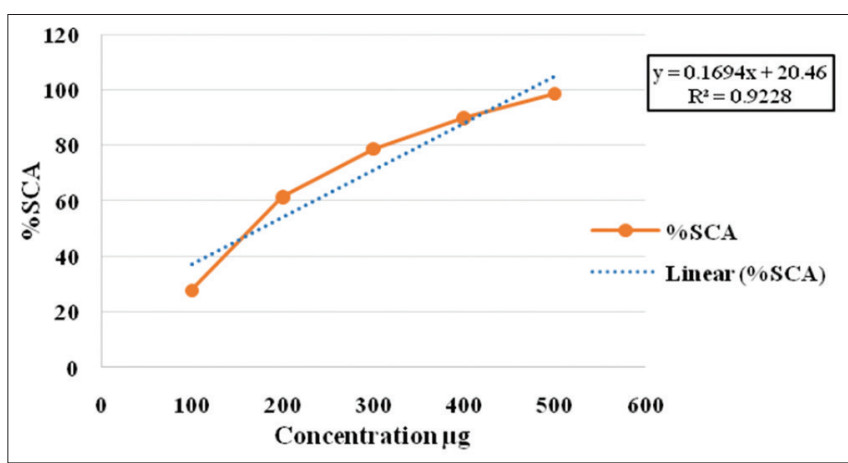

Fig. 3: The 1-diphenyl-2-picrylhydrazyl scavenging activities of Sphaeranthus indicus water extract

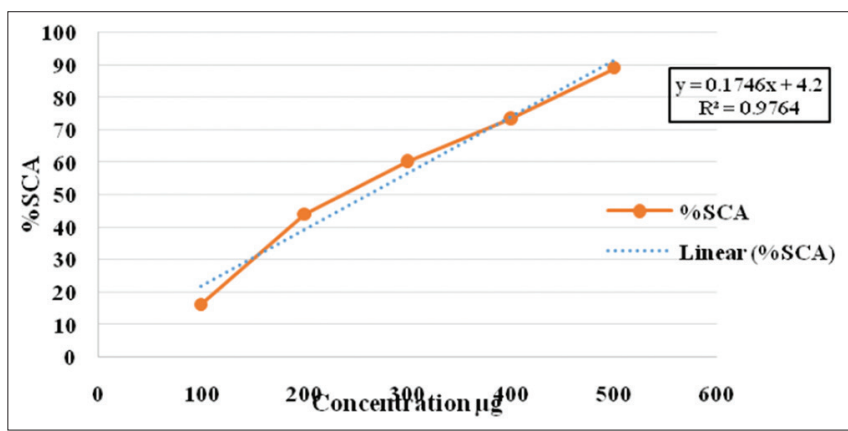

Fig. 4: The 1-diphenyl-2-picrylhydrazyl scavenging activities of Psophocarpus tetragonolobus water extract

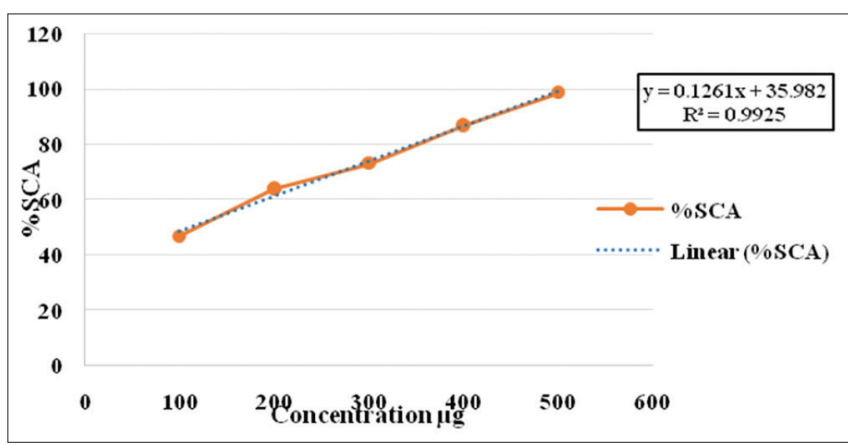

Fig. 5: The 1-diphenyl-2-picrylhydrazyl scavenging activity of standard (ascorbic acid) 


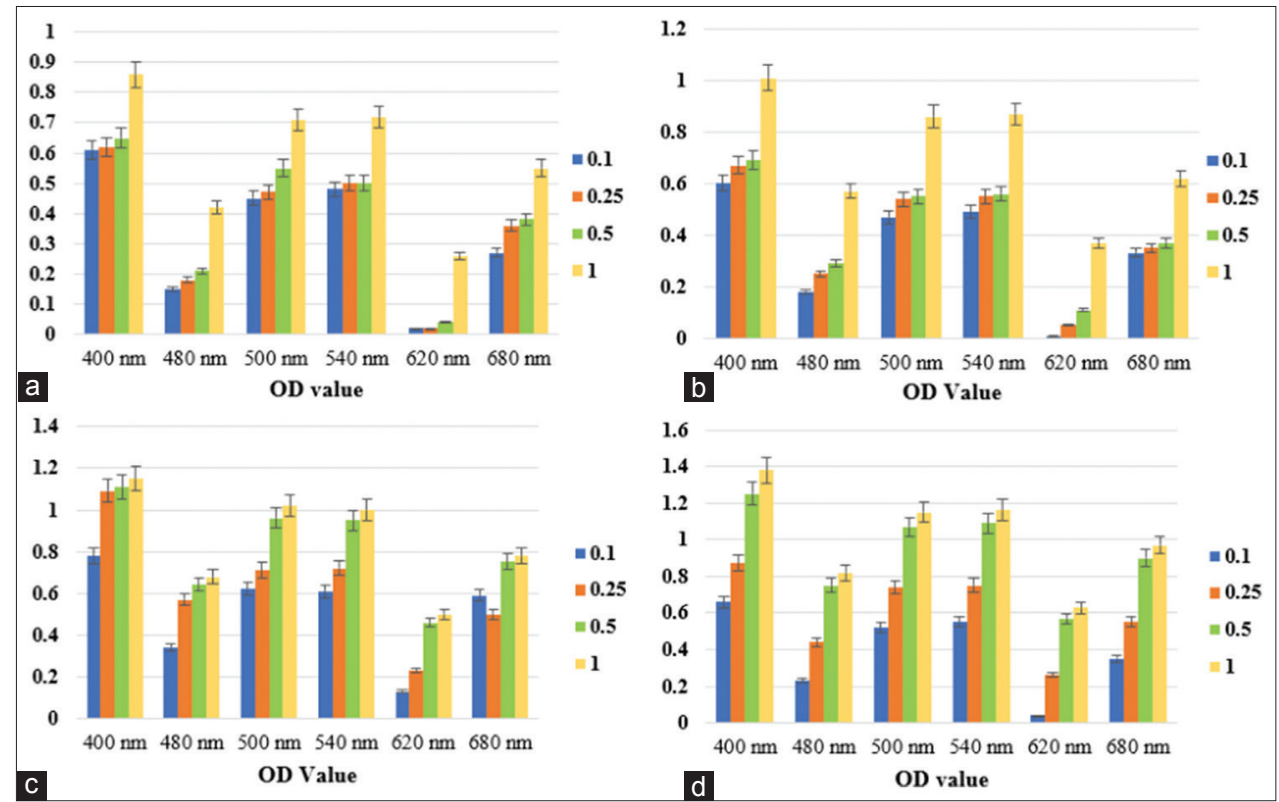

Fig. 6: (a-d) The FRAP assay results for of Sphaeranthus indicus water, hexane, ethanol, and methanol extracts, respectively.

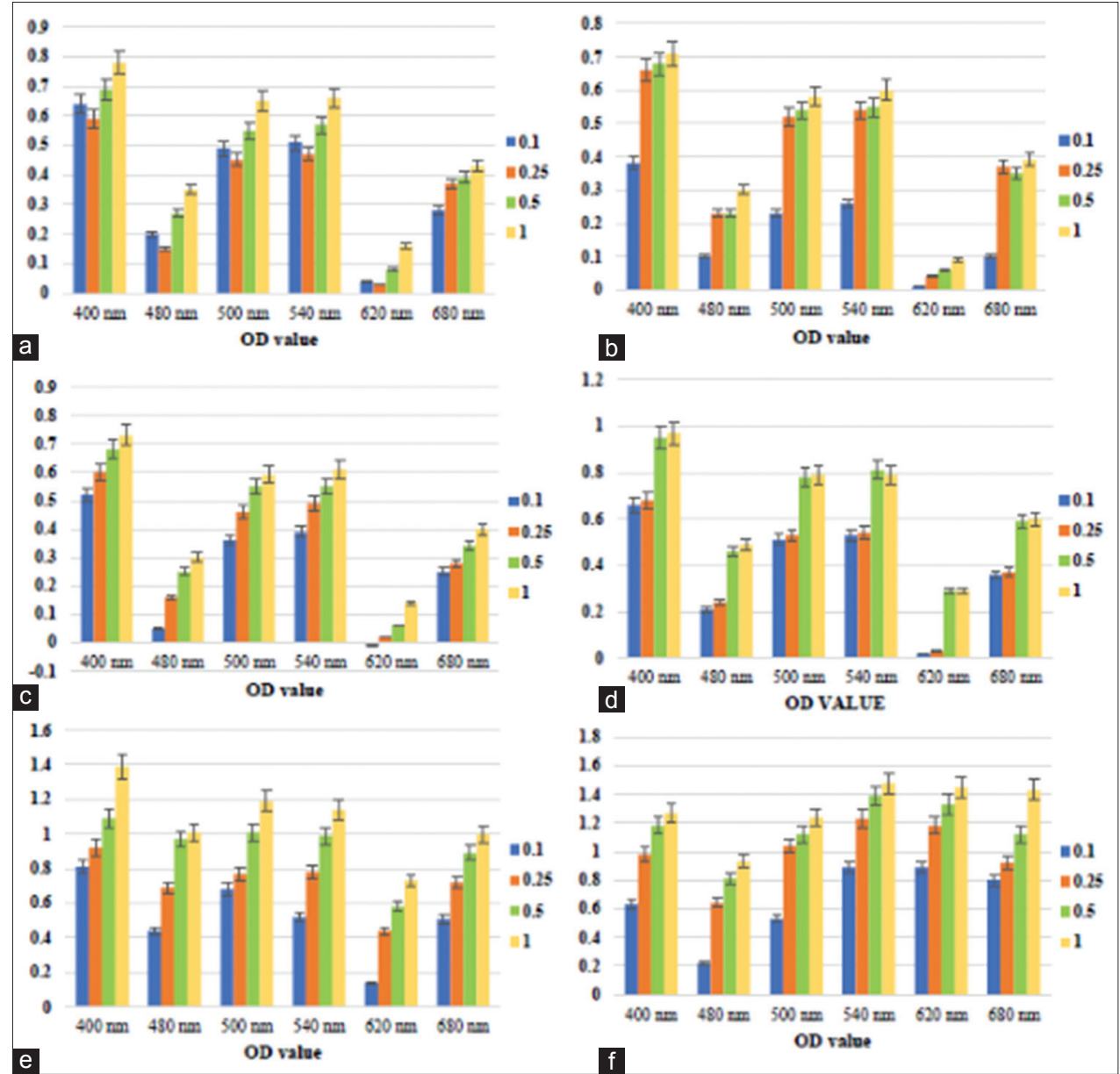

Fig. 7: (a-f) The FRAP assay results for of Psophocarpus tetragonolobus water, hexane, ethanol, and methanol extracts and standard, ascorbic acid and quercetin respectively

compared with standards, ascorbic acid and quercetin. The $\mathrm{IC}_{50}$ value of $S$. indicus, P. tetragonolobus, ascorbic acid, and quercetin was 70.065, $151.953,85.162$, and 79.647 , respectively. These results clearly indicate that $S$. indicus methanolic fraction had better antioxidant activity when compared to both the standards.
In $S$. indicus, the $\mathrm{IC}_{50}$ values were $123.22,131.43$, and 173.33 for hexane, ethanol, and water extracts, respectively, and those of $P$. tetragonolobus were 214.30, 243.79, and 283.18, for hexane, ethanol, and water, respectively. From the above results, it is clear that the FRAP results for other three extracts for both plants indicated that 
Table 2: The DPPH scavenging activities of Sphaeranthus indicus and Psophocarpus tetragonolobus water extracts as compared to the standard, ascorbic acid

\begin{tabular}{|c|c|c|c|c|c|c|}
\hline \multirow{2}{*}{$\begin{array}{l}\text { Reagents } \\
\text { Methanol ml }\end{array}$} & \multirow{2}{*}{$\begin{array}{l}\text { Blank } \\
3.7\end{array}$} & \multicolumn{5}{|c|}{ Sphaeranthus indicus water extract } \\
\hline & & 3.7 & 3.7 & 3.7 & 3.7 & 3.7 \\
\hline $\mathrm{DPPH} \mu \mathrm{l}$ & 200 & 200 & 200 & 200 & 200 & 200 \\
\hline Sample mg & & 100 & 200 & 300 & 400 & 500 \\
\hline Water $\mu \mathrm{l}$ & 100 & 100 & 100 & 100 & 100 & 100 \\
\hline \multicolumn{7}{|l|}{ Incubation at dark for $30 \mathrm{~min}$} \\
\hline $\mathrm{OD}$ at $517 \mathrm{~nm}$ & 0.568 & 0.405 & 0.219 & 0.121 & 0.058 & 0.008 \\
\hline \% Scavenging antioxidant activity & & 28 & 61.4 & 78.7 & 89.8 & 98.5 \\
\hline $\mathrm{IC}_{50}$ Value & & 174.380 & & & & \\
\hline Standard error & & 0.070182 & & & & \\
\hline Reagents & Blank & \multicolumn{5}{|c|}{ Psophocarpus tetragonolobus water extract } \\
\hline Methanol ml & 3.7 & 3.7 & 3.7 & 3.7 & 3.7 & 3.7 \\
\hline DPPH $\mu \mathrm{l}$ & 200 & 200 & 200 & 200 & 200 & 200 \\
\hline Sample mg & & 100 & 200 & 300 & 400 & 500 \\
\hline Water $\mu \mathrm{l}$ & 100 & 100 & 100 & 100 & 100 & 100 \\
\hline \multicolumn{7}{|l|}{ Incubation at dark for $30 \mathrm{~min}$} \\
\hline $\mathrm{OD}$ at $517 \mathrm{~nm}$ & 0.568 & 0.475 & 0.318 & 0.225 & 0.151 & 0.063 \\
\hline $\mathrm{IC}_{50}$ Value & & 262.313 & & & & \\
\hline Standard error & & 0.070915 & & & & \\
\hline Reagents & Blank & \multicolumn{5}{|c|}{ Ascorbic acid } \\
\hline Methanol ml & 3.7 & 3.7 & 3.7 & 3.7 & 3.7 & 3.7 \\
\hline $\mathrm{DPPH} \mu \mathrm{l}$ & 200 & 200 & 200 & 200 & 200 & 200 \\
\hline Sample mg & & 100 & 200 & 300 & 400 & 500 \\
\hline Water $\mu \mathrm{l}$ & 100 & 100 & 100 & 100 & 100 & 100 \\
\hline \multicolumn{7}{|l|}{ Incubation at dark for $30 \mathrm{~min}$} \\
\hline $\mathrm{OD}$ at $517 \mathrm{~nm}$ & 0.568 & 0.302 & 0.199 & 0.153 & 0.075 & 0.08 \\
\hline \% Scavenging antioxidant activity & & 46.8 & 64 & 73.06 & 86.7 & $98.5 \%$ \\
\hline $\mathrm{IC}_{50}$ value & & 111.16 & & & & \\
\hline Standard error & & 0.042037 & & & & \\
\hline
\end{tabular}

DPPD: 1-diphenyl-2-picrylhydrazyl

Table 3: The FRAP assay results for all the extracts of Psophocarpus tetragonolobus leaves

\begin{tabular}{|c|c|c|c|c|c|c|}
\hline \multirow[t]{2}{*}{ Concentration $(100 \mathrm{ml} / \mathrm{ml})$} & \multicolumn{6}{|l|}{ Absorbance } \\
\hline & $400 \mathrm{~nm}$ & $480 \mathrm{~nm}$ & $500 \mathrm{~nm}$ & $540 \mathrm{~nm}$ & $620 \mathrm{~nm}$ & $680 \mathrm{~nm}$ \\
\hline \multicolumn{7}{|l|}{ Psophocarpus tetragonolobus water } \\
\hline $0.25 \mathrm{ml}$ & 0.59 & 0.15 & 0.45 & 0.47 & 0.03 & 0.37 \\
\hline $0.50 \mathrm{ml}$ & 0.69 & 0.27 & 0.55 & 0.57 & 0.08 & 0.39 \\
\hline $1.00 \mathrm{ml}$ & 0.78 & 0.35 & 0.65 & 0.66 & 0.16 & 0.43 \\
\hline Standard error & 0.03508917 & 0.03764555 & 0.0376663 & 0.03577272 & 0.02558686 & 0.02747158 \\
\hline $\mathrm{IC}_{50}$ & 262.82 & 247.88 & 239.19 & 253.13 & 342.63 & 353.46 \\
\hline Average $\mathrm{IC}_{50}$ & 283.185 & & & & & \\
\hline \multicolumn{7}{|l|}{ Psophocarpus tetragonolobus hexane } \\
\hline $0.10 \mathrm{ml}$ & 0.38 & 0.10 & 0.23 & 0.26 & 0.01 & 0.10 \\
\hline $0.25 \mathrm{ml}$ & 0.66 & 0.23 & 0.52 & 0.54 & 0.04 & 0.37 \\
\hline $0.50 \mathrm{ml}$ & 0.68 & 0.23 & 0.54 & 0.55 & 0.06 & 0.35 \\
\hline $1.00 \mathrm{ml}$ & 0.71 & 0.30 & 0.58 & 0.60 & 0.09 & 0.39 \\
\hline Standard error & 0.06627358 & 0.03614208 & 0.06940596 & 0.06664974 & 0.01457738 & 0.05888283 \\
\hline $\mathrm{IC}_{50}$ & 179.03 & 274.76 & 169.85 & 172.79 & 273.9 & 215.51 \\
\hline Average $\mathrm{IC}_{50}$ & 214.307 & & & & & \\
\hline \multicolumn{7}{|l|}{ Psophocarpus tetragonolobus ethanol } \\
\hline $0.10 \mathrm{ml}$ & 0.52 & 0.05 & 0.36 & 0.39 & -0.01 & 0.25 \\
\hline $0.25 \mathrm{ml}$ & 0.60 & 0.16 & 0.46 & 0.49 & 0.02 & 0.28 \\
\hline $0.50 \mathrm{ml}$ & 0.68 & 0.25 & 0.55 & 0.55 & 0.06 & 0.34 \\
\hline $1.00 \mathrm{ml}$ & 0.73 & 0.30 & 0.59 & 0.61 & 0.14 & 0.40 \\
\hline Standard error & 0.03990222 & 0.04756574 & 0.04430011 & 0.04062019 & 0.02814583 & 0.0288043 \\
\hline $\mathrm{R}^{2}$ & 0.8726 & 0.8309 & 0.8179 & 0.807 & 0.9987 & 0.9722 \\
\hline $\mathrm{IC}_{50}$ & 226.71 & 196.71 & 211.59 & 224.8 & 303.72 & 299.21 \\
\hline Average $\mathrm{IC}_{50}$ & 243.79 & & & & & \\
\hline \multicolumn{7}{|l|}{ Psophocarpus tetragonolobus methanol } \\
\hline $0.10 \mathrm{ml}$ & 0.66 & 0.21 & 0.51 & 0.53 & 0.02 & 0.36 \\
\hline $0.25 \mathrm{ml}$ & 0.68 & 0.24 & 0.53 & 0.54 & 0.03 & 0.37 \\
\hline $0.50 \mathrm{ml}$ & 0.95 & 0.46 & 0.78 & 0.81 & 0.29 & 0.59 \\
\hline $1.00 \mathrm{ml}$ & 0.97 & 0.49 & 0.79 & 0.79 & 0.29 & 0.60 \\
\hline Standard error & 0.07267221 & 0.06294839 & 0.06636782 & 0.06636782 & 0.06627358 & 0.05755432 \\
\hline $\mathrm{R}^{2}$ & 0.7608 & 0.796 & 0.7432 & 0.6668 & 0.7146 & 0.742 \\
\hline
\end{tabular}


Table 4: The FRAP assay results for standards, ascorbic acid and quercetin

\begin{tabular}{|c|c|c|c|c|c|c|c|}
\hline & \multirow{2}{*}{$\begin{array}{l}\text { Concentration }(100 \mathrm{mg} / \\
\mathrm{ml})\end{array}$} & \multicolumn{6}{|l|}{ Absorbance } \\
\hline & & $400 \mathrm{~nm}$ & $480 \mathrm{~nm}$ & $500 \mathrm{~nm}$ & $540 \mathrm{~nm}$ & $620 \mathrm{~nm}$ & $680 \mathrm{~nm}$ \\
\hline \multicolumn{8}{|l|}{ Ascorbic acid } \\
\hline $0.10 \mathrm{ml}$ & & 0.81 & 0.44 & 0.68 & 0.52 & 0.14 & 0.51 \\
\hline $0.25 \mathrm{ml}$ & & 0.92 & 0.69 & 0.77 & 0.78 & 0.44 & 0.72 \\
\hline $0.50 \mathrm{ml}$ & & 1.09 & 0.97 & 1.01 & 0.99 & 0.58 & 0.89 \\
\hline $1.00 \mathrm{ml}$ & & 1.39 & 1.01 & 1.19 & 1.14 & 0.73 & 1.00 \\
\hline Standard error & & 0.10945176 & 0.11529175 & 0.10027306 & 0.11653192 & 0.10882182 & 0.09253378 \\
\hline $\mathrm{R}^{2}$ & & 0.9982 & 0.7513 & 0.9518 & 0.8615 & 0.8233 & 0.8488 \\
\hline $\mathrm{IC}_{50}$ & & 76.91 & 84.6 & 86.17 & 78.07 & 86.15 & 99.07 \\
\hline Average $\mathrm{IC}_{50}$ & & 85.162 & & & & & \\
\hline \multicolumn{8}{|l|}{ Quercetin } \\
\hline $0.10 \mathrm{ml}$ & & 0.63 & 0.22 & 0.53 & 0.89 & 0.89 & 0.80 \\
\hline $0.25 \mathrm{ml}$ & & 0.98 & 0.64 & 1.04 & 1.23 & 1.18 & 0.92 \\
\hline $0.50 \mathrm{ml}$ & & 1.18 & 0.81 & 1.12 & 1.39 & 1.33 & 1.12 \\
\hline $1.00 \mathrm{ml}$ & & 1.27 & 0.93 & 1.24 & 1.48 & 1.45 & 1.43 \\
\hline Standard error & & 0.12290749 & 0.1343968 & 0.13538718 & 0.11249306 & 0.10466464 & 0.11923585 \\
\hline $\mathrm{R}^{2}$ & & 0.839 & 0.7331 & 0.6372 & 0.7352 & 0.8001 & 0.9953 \\
\hline $\mathrm{IC}_{-}$ & & 79.25 & 73.72 & 77.93 & 86.79 & 89.47 & 70.72 \\
\hline Average $\mathrm{IC}_{50}$ & & 79.647 & & & & & \\
\hline
\end{tabular}

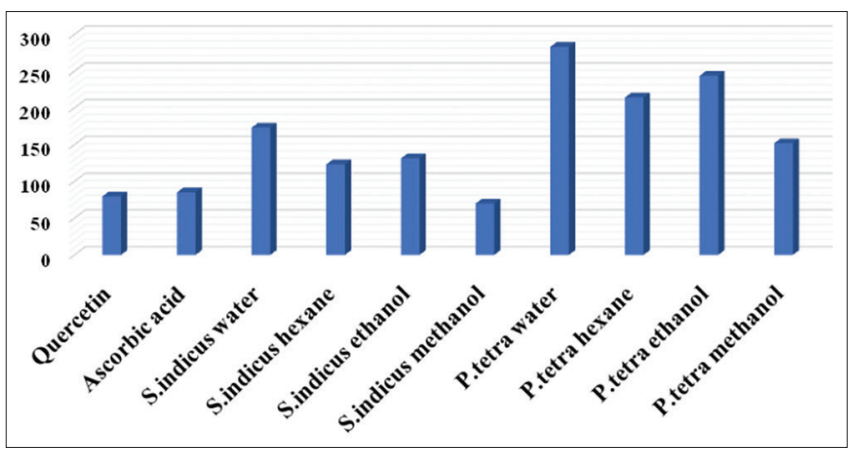

Fig. 8: The comparative $I_{50}$ values for FRAP assay for all the extracts of Sphaeranthus indicus and Psophocarpus tetragonolobus leaves and for standards, ascorbic acid and quercetin

hexane fraction gave comparatively better results than those of water and ethanol.

\section{CONCLUSION}

Thus, from these two antioxidant assays, it is concluded that $S$. indicus and $P$. tetragonolobus have excellent antioxidant activities which could be major contributing factors for their medicinal roles.

\section{ACKNOWLEDGMENTS}

The authors are deeply indebted to all who have directly or indirectly supported this work.

\section{AUTHORS' CONTRIBUTIONS}

All the authors have equally contributed toward the designing, experimentation, and preparation of the manuscript.

\section{CONFLICTS OF INTEREST}

The authors declare that no conflicts of interest exist among them.

\section{REFERENCES}

1. Sivagnanam SK, Rao MR, Choudhury S. In vitro antibacterial efficacy of Mucuna pruriens and Vetiveriazi zanoides on selected human pathogens. Indo Am Pharm Res 2018;8:1281-6.

2. Rao MR, Anisha G. Preliminary phytochemical and GC MS study of one medicinal plant Carissa spinarum. Indo Am J Pharm Res 2018;8:414-21.
3. Rao MR, Balasubramaniam M. TLC, GC MS and antibacterial study of methanol extracts of Tribulus terrestris thorns and Morinaga oleifera flowers. Indo Am J Pharm Res 2018;5:3300-8.

4. Shil S, Rao MR, Prabhu K, Amuthvalli K. Thin layer chromatography -As a tool for standardization of ayurvedic medicine, trikatuchurna. Indo Am J Pharm Res 2018;5:5039-46.

5. Kotteswari M, Rao MR, Kumar S, Prabhu K, Sundaram RL, Dinakar S. GC MS analysis of one ayurvedic preparation aswagandharishtam. Biomed Pharm J 2018;11:1061-72.

6. Donkor MN, Ayikanle SY, Adoesomdonkor S. Effect of ethanol stem bark extract of Berlina grandiflora Hutch and Dalz on marker liver enzymes in rats treated with. Int J Pharm Pharm Sci 2018;10:69-7.

7. Suwandi JF, Wijayanti MA. In vitro antiplasmodial and cytotoxic activities of a Sungkai (Peronema canescens) leaf extract. Int J Pharm Pharm Sci 2018;10:109-13.

8. Mahajan NG, Chopda MZ, Mahajan RT. A review on Sphaeranthus indicus Linn: Multipotential medicinal plant. Int J Pharm Res All Sci 2015;4:48-74.

9. Galani VJ, Patel BG, Rana DG. Sphaeranthus indicus Linn: A phytopharmacological review. Int J Ayrveda Res 2010;1:247-52.

10. Zachariah SM, Pappachen LK, Aneesh TP, Alex L, Sumith G, John MS, et al. Phytochemical and pharmacological screening of Sphaeranthus indicus Linn. For antimicrobial activity. Int J Pharm Sci Res 2010;1:169-73.

11. Nanda BK, Jena J, Rath B, Behera BR. Analgesic and antipyretic activity of whole parts of Sphaeranthus indicus Linn. J Chem Pharm Res 2009; 1:207-12.

12. Nahata A, Saxena A, Suri N, Saxena AK, Dixit VK. Sphaeranthus indicus induces apoptosis through mitochondrial- dependent pathway in HL-60 cells and exerts cytotoxic potential on several human cancer cell lines. Integr Cancer Ther 2013;12:236-47.

13. Krishna TM, Thota SP, Jadhav M, Kamal KM, Venuganti A, Mrunalini D, et al. Studies on in vitro antioxidant and antibacterial activities of Sphaeranthus indicus (Linn). Int J Pharm Res Biomed Anal 2013;2:1-9.

14. Sundari K, Karthik D, Ilavenil S, Kaleeswaran B, Srigopalram S, Ravikumar S. Hepatoprotective and proteomic mechanism of Sphaeranthus indicus in paracetamol induced hepatotoxicity in Wistar rats. Food Biosci 2013;1:57-65.

15. Muhammad RT, Malik S, Ghulam M, Waseem H. Determination of the antidiabetic effect of methanolic extract of Sphaeranthus indicus L. On alloxan induced diabetic rabbits. Lat Am J Pharm 2011;30:378-82.

16. Meher BR, Mahar B, Rath BG, Sahoo SK. Antimicrobial activity of ethanolic extracts of leaves of Sphaeranthus indicus. Der Pharm Lett 2013;5:8-10

17. Rao MR, Vijayalakshmi N. Preliminary phytochemical and GC MS analysis of different extracts of Sphaeranthus indicus leaves. Indo Am J Pharm Sci 2018;5:1511-20.

18. Lee KH, Padzil AM, Syahida A, Abdullah N, Zuhainis SW, Maziah M, et al. Evaluation of anti-inflammatory, antioxidant and anti-nociceptive activities of six Malaysian medicinal plants. J Med Plants Res 
2011;5:5555-63.

19. Sasidharan S, Zuraini Z, Yoga LL, Sangetha S, Suryani S. Antimicrobial activities of Psophocarpus tetragonolobus (L.) DC extracts. Food Borne Pathog Dis 2008;5:303-9.

20. Hamid R, Masood A, Wani IH, Rafiq S. Lectins: Proteins with diverse applications. J Appl Pharm Sci 2013;3 4 Suppl 1:S93-103.

21. Latha LY, Sasidharan S, Zuraini Z, Suryani S, Shirley L, Sangetha S, et al. Activity and toxicity of crude extract of the Psophocarpus tetragonolobus Pods. Afr J Trad Compl Alter Med 2007;4:59-63.

22. Rao MR, Lakshmi NV, Sundaram RL. Preliminary phytochemical and GC MS analysis of different extracts of Psophocarpus tetragonolobus leaves. Int Appl J Pharm Sci 2018;5:1649-56.

23. Solver-Rivas C, Espín JS, Wichers HJ. An easy and fast test to compare total free radical scavenger capacity of food stuffs. Phytochem Anal 2000; $11: 330-8$.

24. Braca A, Sortino C, Politi M. Antioxidant activity of flavonoids from Licanialicaniaeflora. J Ethnopharm 2002;9:379-81.

25. Yen GC, Duh PD. Scavenging effect of methanolic extracts of peanut hulls on free-radical and active-oxygen species. J Agric Food Chem 1994;42:629-32.

26. Oyaizu M. Studies on product of browning reaction prepared from glucose amine. Jpn J Nutr 1986; 7:307-15 